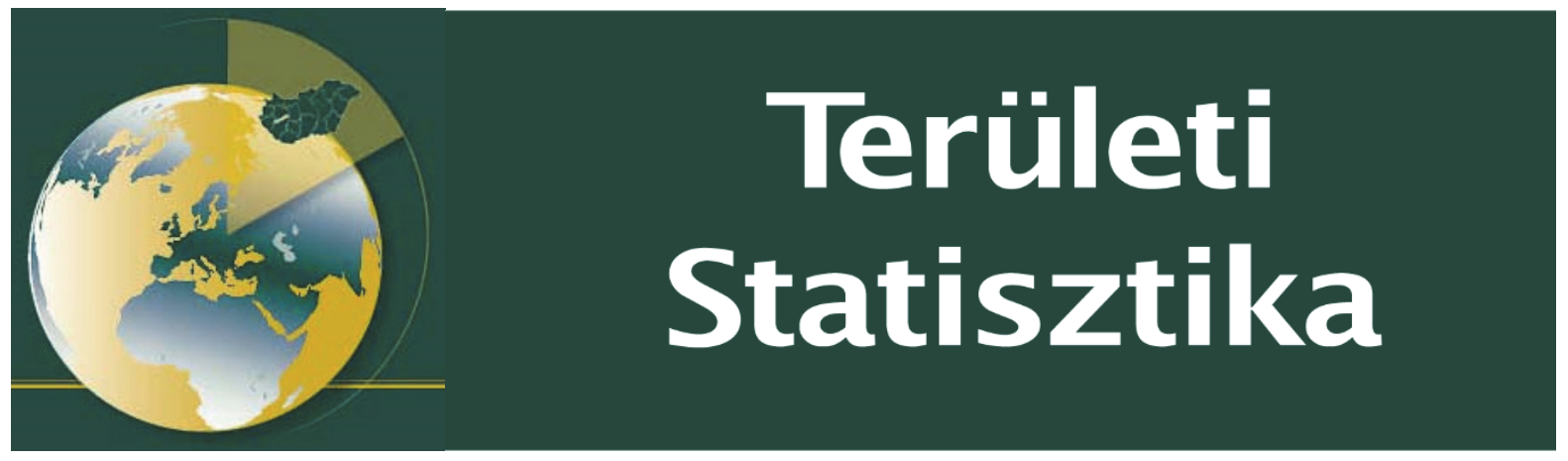

Közzététel: 2020. március 2.

A tanulmány címe:

Olyan jó egyedül? - A szinglik érzelmi állapota, élettel való elégedettsége a 2016. évi mikrocenzus adatai alapján

Szerzők:

Rövid Irén

https://doi.org/10.15196/TS600206

Az alábbi feltételek érvényesek minden, a Központi Statisztikai Hivatal (a továbbiakban: KSH) Területi Statisztika c. folyóiratában (a továbbiakban: Folyóirat) megjelenó tanulmányra. Felhasználó a tanulmány, vagy annak részei felhasználásával egyidejüleg tudomásul veszi a jelen dokumentumban foglalt felhasználási feltételeket, és azokat magára nézve kötelezónek fogadja el. Tudomásul veszi, hogy a jelen feltételek megszegéséböl eredö valamennyi kárért felelösséggel tartozik.

1) A jogszabályi tartalom kivételével a tanulmányok a szerzői jogról szóló 1999. évi LXXVI. törvény (Szjt.) szerint szerzői műnek minősülnek. A szerzői jog jogosultja a KSH.

2) A KSH földrajzi és időbeli korlátozás nélküli, nem kizárólagos, nem átadható, térítésmentes felhasználási jogot biztosít a Felhasználó részére a tanulmány vonatkozásában.

3) A felhasználási jog keretében a Felhasználó jogosult a tanulmány:

a) oktatási és kutatási célú felhasználására (nyilvánosságra hozatalára és továbbítására a

4. pontban foglalt kivétellel) a Folyóirat és a szerző(k) feltüntetésével;

b) tartalmáról összefoglaló készítésére az írott és az elektronikus médiában a Folyóirat és a szerző(k) feltüntetésével;

c) részletének idézésére - az átvevő mű jellege és célja által indokolt terjedelemben és az eredetihez híven - a forrás, valamint az ott megjelölt szerző(k) megnevezésével.

4) A Felhasználó nem jogosult a tanulmány továbbértékesítésére, haszonszerzési célú felhasználására. Ez a korlátozás nem érinti a tanulmány felhasználásával előállított, de az Szjt. szerint önálló szerzői műnek minősülő mű ilyen célú felhasználását.

5) A tanulmány átdolgozása, újra publikálása tilos.

6) A 3. a)-c.) pontban foglaltak alapján a Folyóiratot és a szerző(ke)t az alábbiak szerint kell feltüntetni:

„Forrás: Területi Statisztika c. folyóirat 60. évfolyam 2. sqámában megjelent, Rövid Irén által irt Olyan jó egyedül? - A szinglike érzelmi állapota, élettel való elégedettsége a 2016. évi mikerocenzus adatai alapján c. tanulmány”

7) A Folyóiratban megjelenő tanulmányok kutatói véleményeket tükröznek, amelyek nem esnek szükségképpen egybe a KSH, vagy a szerzők által képviselt intézmények hivatalos álláspontjával. 


\section{Olyan jó egyedül? - A szinglik érzelmi állapota, élettel való elégedettsége a 2016. évi mikrocenzus adatai alapián *}

\section{Is it so good to be alone? - The emotional state and life satisfaction of singles on the basis of the $\mathbf{2 0 1 6}$ microcensus}

\footnotetext{
Rövid, Irén A tanulmány az egyedülállók - a külön háztartásKözponti Statisztikai Hivatal, PTE-BTK Demográfia és Szociológia Doktori Iskola

E-mail: iren.rovid@gmail.com ban egyedül élők - egy szűkebb csoportjának, az úgynevezett szingliknek az életkörülményeit, szubjektív jóllétét vizsgálja a 2016. évi mikrocenzus adatai alapján. Választ keres arra a kérdésre, hogy milyen gyakran éltek meg boldog és magányos érzelmi állapotokat, mennyire voltak elégedettek az életükkel és annak meghatározott területeivel. Célja az is, hogy a szubjektív mutatók alapján elhelyezze a szingliket a társadalomban, és rámutasson a Magyarországon belüli főbb területi különbségekre. Ismerteti továbbá, hogyan alakult a szinglik száma és népességen belüli aránya 2001 és 2016 között, valamint milyen jellemzői voltak egy ,átlagos” szinglinek 2016-ban.

Kulcsszavak: Kutatások tapasztalatai szerint a tartós párkapszinglik, csolatban, különösen a házastársukkal élők bolszubjektív jóllét, dogabbak, elégedettebbek az életükkel, mint mikrocenzus, boldogság, magányosság a szinglik. A tanulmány célja ezért az is, hogy összehasonlítsa a szinglik mutatóit a házasságban élőkével.
}

* A jelen dokumentum a Központi Statisztikai Hivatal 2001. és 2011. évi népszámlálás, valamint 2016. évi mikrocenzus adatállományainak felhasználásával készült. A dokumentumban foglalt számítások és az azokból levont következtetések kizárólag Rövid Irén mint szerző szellemi termékei. 
The study examines the living conditions and subjective well-being of a smaller group of the one-person households - those who lives in separated households - the so-called "Singles" on the Basis of 2016 Microcensus. It seeks answer for that how often lived happy and lonely emotional state and how much were they satisfied with their lives and it's designated areas according to the results of the survey. Furthermore it is seeking to place singles in society based on subjective indicators show on to the differences in the main areas in Hungary. It also aims to explain how the number and proportion of Singles changed between 2001 and 2016, as well as the characteristics of an

Keywords: "average" single in 2016. Research has shown singles, that in long-term relationships, especially with subjective well-being, their spouses, they are happier, more satisfied microcensus, with their lives than Singles. Therefore, the happiness, purpose of the study is to compare the values of loneliness Singles with married people.

Beküldve: 2019. szeptember 23.

Elfogadva: 2020. január 17.

\section{Bevezetés}

Az 1960-as évek óta jelentősen megváltozott a családok összetétele Európában. Míg a házasságon alapuló, hagyományos családforma veszített súlyából, addig alternatív együttélési formák jelentek meg, váltak egyre elterjedtebbé, ami változatosabbá tette a családformákat. Bár az európai országok családstruktúrája között különbségek is vannak, mégis az utóbbi évtizedekben a házasságban élők száma valamennyi esetében csökkent, ugyanakkor egyre többen élnek élettársi kapcsolatban, vállalnak gyermeket házasságon kívül is. Nőtt az egyszülős és a mozaikcsaládok, valamint a látogató kapcsolatban élők aránya is (Sobotka-Toulemon 2008). Az átalakulás további, jelen tanulmány szempontjából legfontosabb jellemzóje, hogy többek között a házasságkötés halasztása, a válási arányszám és a várható élettartam emelkedése miatt (DePaulo-Morris 2005, Cockrum-White 1985) egyre többen élnek egyedül (Földházi 2008, Harcsa-Monostori 2014, Monostori 2013, 2015, Monostori-Murinkó 2018, Schadt-Pótó 2014, Somlai 1999, 2002, Spéder 2005a, 2005b, 2007, SpéderKamarás 2008, Tóth 2006, Sobotka-Toulemon 2008).

Területi Statisztika, 2020, 60(2): 224-248; DOI: 10.15196/TS600206 
A közép-kelet-európai országok többségéhez hasonlóan, Magyarországon is az 1990-es években kezdett el jelentősen csökkeni a teljes első házasságkötési arányszám, ${ }^{1}$ ami arra utal, hogy a nők egy jelentős része nem köti meg az első házasságát 50 éves koráig. Míg 1960-ban a száz nőre számított mutató 100 volt, azaz az adott év házasságkötési gyakoriságának tartós fennállása esetén az előbb említett életkorig minden hajadon megkötötte volna első házasságát, addig ezt követően csökkent a mutató. A mélypontot jelentő 2010-ben 39-re esett vissza ez az arányszám, ami 2011-ben stagnált, majd újra emelkedni kezdett. A házasságon alapuló párkapcsolatok számának mérséklődését okozhatta az is, hogy a rendszerváltást követően jelentősen nőtt az élettársi kapcsolatban élők aránya. Továbbá az 1990-es évekhez képest jelentôsen kitolódott az első házasságkötés átlagos életkora is (Sobotka-Toulemon 2008, Harcsa-Monostori 2014, KSH 2019).

Bár a házasságban élők száma és aránya az utóbbi évtizedekben csökkent, a 2016. évi mikrocenzus adatai szerint a népesség 36\%-a továbbra is házasságon alapuló párkapcsolatban, 9,9\%-a azonban élettársi kapcsolatban élt hazánkban. Míg az előbbiek aránya 8,9 százalékponttal mérséklődött, addig utóbbiaké 7,4 százalékponttal nőtt 1990 és 2016 között. A gyermeküket egyedül nevelő szülők aránya ugyanebben az időszakban 4,3-ról 5,1\%-ra, az egyedülállóké - a külön háztartásban egyedül élóké - pedig 9,1-rôl 12,0\%-ra emelkedett (KSH 2018a).

Az életkörülményeket nemcsak objektív tényezők mentén mutatjuk be, hanem a szubjektív, egyéni értékelésen alapuló mutatók mentén is. Utóbbiakat azért tartjuk fontosnak, mert korábbi kutatások tapasztalatai szerint az egyén szubjektív jólléte, életminősége összefügg a családi állapotával, különösen azzal, hogy van-e tartós párkapcsolata. Azok ugyanis, akiknek nincsen állandó partnerük, azaz szinglik, gyakrabban érzik magukat magányosnak, elégedetlenebbek az életükkel, mint a velük egykorú párkapcsolatban, házasságban élők (Cargan 1981, DePaulo-Morris 2005, Diener et al. 1999, Haller-Hadler 2006, Hertel et al. 2007, Hradil 1995, 2003, Ho 2015, Shapiro-Keyes 2008, Verbakel 2012). Éppen ezért a szinglik szubjektív jóllétének bemutatása mellett a kapott eredményeket a házasságban élőkével is öszszehasonlítjuk.

A tanulmány első fejezete a szinglik fogalmát határozza meg a hazai és a külföldi kutatásokban használt definíciók bemutatásán, értelmezésén keresztül. Ezt követően ismerteti a kutatás kiindulópontját jelentő elméleteket. Az empirikus rész tartalmazza a 2001. és a 2011. évi népszámlálás, valamint a 2016. évi mikrocenzus adatai alapján végzett kutatás eredményeit, majd a főbb megállapítások összefoglalásával zárul a tanulmány.

1 A nők teljes első házasságkötési arányszáma azt fejezi ki, hogy az adott év házasságkötési gyakoriságának tartós megmaradása esetén száz hajadon közül hányan kötnek házasságot 50 éves korukig. Forrás: KSH.

Területi Statisztika, 2020, 60(2): 224-248; DOI: 10.15196/TS600206 


\section{A szinglik fogalmának értelmezési keretei}

Számos szakirodalom foglalkozik a szinglik számának, jellemzőinek vizsgálatával, melyek azonban sok esetben eltérnek egymástól abban, hogy kit is tekintenek szinglinek. Nem létezik tehát egy egységes fogalom (Hradil 1995, Hertel et al. 2007, DePaulo-Morris 2005, Vaskovics et al. 2000), melyet alapul lehetne venni, így attól függően, hogy melyik definíciót választjuk, más és más eredményre jutunk (Hradil 1995).

A szingli elnevezés az 1970-es években jelent meg először Európában. Az Egyesült Államokból származó fogalomra ekkor még az egyedül élők életformájaként, a tartós párkapcsolat nélkül élő fiatalok saját maguk választotta életmódjaként tekintettek. A definíciónak ezt követően számos változata terjedt el (Hradil 1995), melyek közül a tanulmány szempontjából releváns típusokat mutatjuk be, a teljesség igénye nélkül. Egyre gyakrabban soroltak mindenkit a szinglik közé, akik egyedül éltek. Laslett (1972) például az egyszemélyes háztartások lakóiként tekintett a szinglikre, de több kutatás is a szinglilét egyik fontos jellemzőjének tartotta azt, hogy az e csoportba tartozók egyszemélyes háztartást alkossanak (Hradil 1995, 2003, Vaskovics et al. 2000, Mächler 1995, Rövid 2018).

Hradil (1995) összehasonlította a korábbi, életformára vonatkozó megközelítést az egyedül élőkre használt későbbi fogalommal, és míg az előbbit túl szűknek, és csak keveseket érintőnek, addig az utóbbit túl tágnak találta, amibe sokan, olykor nagyon különböző jellemzőkkel rendelkezők is beletartoznak. Éppen ezért felvetette, hogy az egyedül élőkön belül csak azokat tekintsük szinglinek, akik életkoruknál fogva már családot alapíthattak volna. Hiszen, ha minden egyedül élő szinglinek számítana, akkor Hradil (2003, 40. old.) szerint nem a „szingli terminust” (singles), hanem az „egyedül élők” megnevezést (allein Wohnende) kellene használni.

DePaulo és Morris (2005) szerint a szingliket az alapján szokták meghatározni, hogy milyen jellemzőkkel nem rendelkeznek. Így minden olyan személyt a szinglik közé sorolnak, akik nem házas családi állapotúak. Értelmezésük szerint így a nőtlenek, hajadonok, az elváltak és az özvegyek is ebbe a csoportba tartoznak.

Egyes kutatásokban csak a nőtlen, hajadon családi állapotúakat tekintik szinglinek (Verbakel 2012, Keith 2008, Cargan 1981, Schad-Seifert 2019). Mások, akárcsak Murinkó Lívia és Spéder Zsolt (2015) azokat is bevonták a vizsgálatba, akik korábban már éltek házasságban vagy élettársi kapcsolatban (Laslett 1972, Utasi 2003, 2004, Murinkó-Spéder 2015). Murinkó és Spéder (2015) az egyedülállók közül nemcsak a nőtlen, hajadon családi állapotúakat vizsgálták, hanem azokat is ide sorolták, akik bár házasok voltak, de nem éltek együtt a házastársukkal, illetve elvált vagy özvegy családi állapotúak voltak. Mächler (1995) a nőtlenek, hajadonok mellett az elváltakat is szinglinek tekintette.

Hradil (1995) a törvényes családi állapot szerinti különbségtételt nem tartja fontosnak, hiszen véleménye szerint a házasok is élhetnek tipikus szinglinek tekinthető

Területi Statisztika, 2020, 60(2): 224-248; DOI: 10.15196/TS600206 
életet. Verbakel $(2012,106$. old.) a családi állapot helyett inkább a „jelenlegi párkapcsolati státust" (current partnership status) használta, mert alkalmasabbnak találta a szubjektív jóllétben mutatkozó eltérések vizsgálatára, mint a családi állapotot.

A családi állapot és a háztartás típusa mellett az is fontos szempont lehet, hogy csak azokat tekintsük szinglinek, akiknek nincsen tartós párkapcsolatuk (Hradil 1995, 2003, Vaskovics et al. 2000, Verbakel 2012, Utasi 2004, 2005, MurinkóSpéder 2015, Rövid 2018). Hradil (2003, 41. old.) őket nevezi „pár nélküli szingliknek" (partnerlose singles), akik továbbá 25-54 évesek, és nem él a háztartásukban gyermek. Ismert azonban olyan megközelítés is, amely nem zárja ki a partner létét, ha a két személy külön háztartást alkot (Mächler 1995).

További szempont az is, hogy a szingliknek van-e, lehet-e gyermekük. Számos kutatás határozza meg úgy ezt a népességcsoportot, mint gyermekkel nem rendelkezóket (Vaskovics et al. 2000, Sobotka-Toulemon 2008, Murinkó-Spéder 2015, Rövid 2018). Ugyanis, ha lenne gyermekük, akkor nem szingliknek, hanem gyermeküket egyedül nevelő szülőknek számítanának. Ezzel szemben az is gyakori, hogy az egyedülálló szülóket is a szinglik közé sorolják, ebben az esetben ,gyermekes szingliként" (singles mit kind) nevezik őket (Hradil 1995, 9. old.). Van, aki azokat is szinglinek tekinti, akinek van gyermeke, de nem él vele közös háztartásban (Hradil 1995, 2003).

Nincs konszenzus abban sem, hogy a szinglik milyen életkorúakat jelentenek. Míg például Hradil (1995) a 25-54, Mächler (1995) a 25-55, Sobotka és Toulemon (2008), valamint Cargan (1981) is a 20-34 éveseket vizsgálta, addig a magyar kutatók közül Utasi Ágnes $(2004,2005)$ - az első magyarországi szinglikutatás végrehajtója a 30-40, Murinkó Lívia és Spéder Zsolt (2015) pedig a 30-49 éves korcsoportot választotta. Vannak továbbá olyan megközelítések is, amelyek a szingliket életkoruk alapján több csoportra osztják. Így tett többek között Verbakel (2012) is, aki a 35 évesnél fiatalabb, valamint a 35 éves és idősebb korosztály tagjainak jellemzőit vette szemügyre. DePaulo és Morris (2005) a szinglikkel kapcsolatos sztereotípiák vizsgálatához különböztette meg a fiatalabb és az idősebb szingliket, előbbinek a 25 , utóbbinak a 40 évesek feleltek meg.

A hivatalos statisztika nem tartalmaz definíciót a szinglikre, ami bár némi nehézséget jelent akkor, ha ezt az adatforrást választjuk, mégis - meglátásom szerint - az egyedülállókon belül kialakítható egy szúkebb, szinglinek tekinthető csoport. Korábban Sobotka és Toulemon (2008) is többek között a népszámlálási adatokból indult ki a családszerkezeti változások bemutatása során, és nemzetközi összehasonlításban a szinglik jellemzőire is kitért. Fontos azonban megjegyezni, hogy a cenzusokból nem rendelkezünk arra vonatkozó adatokkal, hogy a szingliéletet az érintettek maguk választották-e, így ezt a szempontot nem vesszük figyelembe kutatásunk során. Érdemes továbbá arra is tekintettel lenni, hogy a népszámlálás és a mikrocenzus módszertana szerint az egyedülállók az egyszemélyes háztartásban élőket jelentik, közöttük nemcsak nőtlen, hajadon, hanem házas, elvált és özvegy családi 
állapotúak is előfordulnak. Az egyedülállók korcsoport szerinti megoszlásából pedig megállapítható, hogy többségük a 60 éves és idôsebb népesség közé tartozott a 2016. évi mikrocenzus eszmei időpontjában (KSH 2018a).

A szinglik csoportjának cenzusok alapján történő leválogatásához valamennyi korábban bemutatott definíciót, kutatási szempontot figyelembe vettünk, és többek között arra az elhatározásra jutottunk, hogy nem minden egyedül élőt tekintünk szinglinek. Bár a szinglilét egyik fontos jellemzőjének tartjuk az egyszemélyes háztartást - Hradilhoz (1995) hasonlóan -, az elóbb említett okok miatt mi is túlzottan heterogénnek találjuk az egyedülállók csoportját. Éppen ezért az önálló háztartás mellett családi állapot és korlátozások mentén párkapcsolat szerint is különbséget teszünk. Továbbá azzal kapcsolatban is állást foglalunk, hogy az általunk vizsgáltaknak van-e, lehet-e gyermekük, illetve melyik korcsoportba tartoznak.

Mindent összevetve, azokat a nőtlen, hajadon családi állapotúakat soroltuk a szinglik közé, akiknek nem volt se élettársuk, se gyermekük, egyedül éltek egy háztartásban, illetve 20-49 évesek voltak. A Magyarországon és a külföldön végzett kutatások sok esetben eltérő korcsoportokra fókuszálnak. Jelen tanulmány alapjául az életkor szempontjából részben Sobotka és Toulemon (2008), illetve Cargan (1981) szolgáltak, akik a szinglik vizsgálatakor a 20. életévet jelölték meg alsó korhatárnak. Ugyanakkor Utasi (2004, 2005), illetve Murinkó és Spéder (2015) definíciójára is építünk a felső korhatár meghatározása során, akik bár az előzőektől eltérő korcsoportos bontást alkalmaztak, 40, illetve 49 éves korig tekintve valakit szinglinek. Akárcsak Verbakel (2012), valamint DePaulo és Morris (2005), úgy mi is két csoportra bontjuk a szingliket, hiszen a 20-39 éves fiatal felnőttek mellett a 40-es éveikben járók jellemzőit is tekintetbe vesszük. A két korcsoportra bontással nemcsak az emberi életszakaszok alapján jól elkülöníthető fiatal felnőttkort, hanem egy, a nők szempontjából még reproduktív kornak számító népességcsoportot is vizsgálhatunk.

\section{Elméleti háttér}

A családok összetételében megfigyelhető változások magyarázatához többnyire a családformák pluralizálódásának tétele szokta a kiindulópontot jelenteni, így jelen tanulmány is többek között ezt az elméletet veszi alapul. Egyes észrevételek szerint a családszerkezeti átalakulások némi időbeli eltéréssel, de követik a második demográfiai átmenet koncepciója által leírt folyamatok ütemét (Harcsa-Monostori 2014, Vaskovics 2014), így röviden ezekkel is foglalkozunk.

\section{Családszerkezeti változások nemzetközi összehasonlításban}

A családformák átalakulására a volt szocialista országokban később került sor, mint a többi európai országban. Míg például a teljes első házasságkötési ráta csökkenése Svédországban és Észak-Európában már az 1960-as évek közepén, Nyugat- és DélEurópában pedig az 1970-es években kezdetét vette, addig a volt szocialista orszá-

Területi Statisztika, 2020, 60(2): 224-248; DOI: 10.15196/TS600206 
gokban, köztük hazánkban is ez csak az 1990-es években következett be (SobotkaToulemon 2008, Tárkányi 2008). Azonban egyes szerzők szerint vitatható, hogy a családszerkezeti változásokra Magyarországon a rendszerváltás vagy inkább az értékek átrendeződésének következményeként tekinthetünk-e (Harcsa-Monostori 2014).

Az 1990 és 2016 közötti időszakot vizsgálva - a nemzetközi folyamatokhoz hasonlóan - Magyarországon is csökkent a házasságban élők népességen belüli aránya, ugyanakkor nőtt az élettársi kapcsolatban élőké. Továbbá egyre nagyobb részét alkotják a társadalomnak az alternatív családformák, melyek közül jelen tanulmány szempontjából az egyszülős családok, valamint a külön háztartásban élő egyedülállók számának és arányának változását vizsgáljuk.

A főbb hazai változásokról megállapíthatjuk, hogy 1990-ben a teljes népesség 45, 2016-ban már csak 36\%-a élt házasságban, miközben az élettársi kapcsolatban élők aránya 2,4-ről 9,9\%-ra emelkedett. ${ }^{2}$ A gyermeküket egyedül nevelő szülők és az egyedülállók népességen belüli aránya 4,3-ről 5,1\%-ra, utóbbié 9,1-rôl 12,0\%-ra nőtt ugyanebben az időszakban (KSH 2018a).

Sobotka és Toulemon (2008) a 2000. és a 2001. évi népszámlálás adatai alapján határozta meg a 20-34 éves gyermektelen szinglik népességen belüli arányát egyes európai országokban. Kutatási eredményeik szerint 2001-ben Magyarországon az ebbe a korcsoportba tartozó férfiak 6,8, a nők 5,6\%-a volt szingli. A magyarországi arány a vizsgált országok rangsorának első felében helyezkedett el, a szomszédos országok közül Ausztriában és Szlovákiában a miénknél magasabb volt a szinglik aránya.

A 2011. évi népszámlálás ${ }^{3}$ alapján a szinglikről nem, de az egyszemélyes háztartások arányáról rendelkezünk adatokkal az Európai Unió valamennyi tagállamára vonatkozóan. A tagállamok többségében a 2011. évi népszámlálás eszmei időpontjában a háztartások több mint 30\%-ában csupán egyetlen személy élt. Az egyszemélyes háztartások aránya azokban az országokban volt a legmagasabb (Finnországban 41, Észtországban 40\%), ahol - a többi észak-európai országhoz hasonlóan - a leghamarabb, már az 1960-as években csökkenni kezdett az első házasságkötési arányszám (Sobotka-Toulemon 2008). Az egyszemélyes háztartások aránya Cipruson és Portugáliában a legalacsonyabb (egyaránt 21\%), miközben a házaspáros típusú háztartások aránya az uniós tagállamok közül ezen országokban volt a legmagasabb. Magyarországon a háztartások 32\%-át csak egy személy alkotta 2011-ben, ezzel az arányunkkal az uniós rangsor középmezőnyében helyezkedtünk el.

2 Az élettársi kapcsolatok alakulásáról az 1990-es évek óta gyűjt adatokat a népszámlálás.

${ }^{3}$ Az adatok forrása az Eurostat honlapján elérhető 2011 Census Hub alkalmazás. 
Az egyszemélyes háztartások aránya az Európai Unió tagállamaiban, 2011

Ratio of one-person households in the Member States of the European Union, 2011

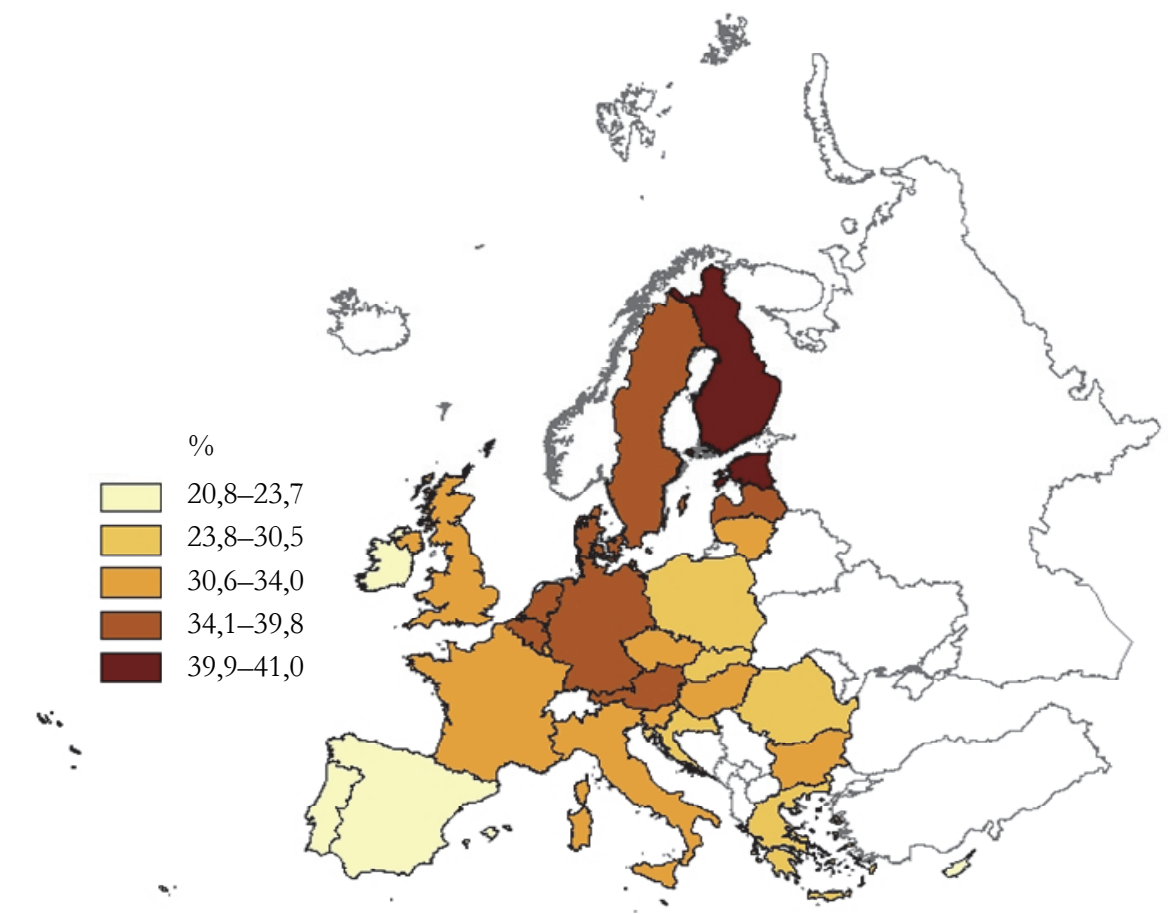

Forrás: Eurostat, saját szerkesztés a 2011. évi népszámlálás adatai alapján.

\section{Második demográfiai átmenet elmélete}

A második demográfiai átmenet koncepciója a demográfiai folyamatokban megfigyelt átalakulásokat a társadalmi értékek megváltozására vezeti vissza. Ennek során a hagyományos értékrenddel szemben ugyanis előtérbe kerültek az egyéni érdekek, melyek a párkapcsolatok felbomlásával, a családdal és a termékenységgel kapcsolatos magatartás megváltozásával is összefüggenek (Lesthaeghe-Sukyn 2012, Murinkó 2013, Sobotka 2008, Spéder 2004, Spéder-Kapitány 2007, Tárkányi 2008, Van de Kaa 2002).

A második demográfiai átmenet elméletének fôbb mozzanatait elsőként Van de Kaa (2002) összegezte. Megállapítása szerint a második demográfiai átmenet hátterében az állt, hogy csökkent a párok motivációja arra, hogy egy vagy két gyermeknél többet vállaljanak, a termékenységi mutatók így a reprodukciós szint alá süllyedtek, mely utóbbiban a gyermekvállalás halasztása is szerepet játszott. A második demográfiai átmenet szerinte többek között olyan folyamatokkal jellemezhető, mint a

Területi Statisztika, 2020, 60(2): 224-248; DOI: 10.15196/TS600206 
születési arányszámok csökkenése, az első házasságkötés átlagos életkorának és a válások számának emelkedése, az élettársi kapcsolatok egyre népszerúbbé válása, a teljes termékenységi arányszám reprodukciós szint alatti stagnálása (Van de Kaa 2002). Vaskovics (2014) a demográfiai változások négy legjelentősebb elemének a posztadoleszcens ${ }^{4}$ életszakasz kialakulását, majd egyre gyakoribbá válását, a családalapítás előfeltételeinek megváltozását, az élettársi kapcsolatok és az azon alapuló családok elterjedését, valamint a születések gyakoriságának csökkenését tartotta.

Tárkányi Ákos (2008) szerint, míg a halálozások száma a második világháborút követően jelentősen csökkent, addig a születéseké emelkedett. Az 1960-as évektől azonban a gazdasági növekedés ütemének lassulásával a társadalom termékenységi mutatója is mérséklődött. A megváltozott gyermekvállalási magatartást a fejlett országokban többek között a nők munkaerőpiacon való tömeges megjelenésével, valamint a fogamzásgátló tabletták elterjedésével magyarázta. 1975 és 1985 között a fejlett országokban mind a házasságkötések száma, mind a termékenység emelkedni kezdett, míg Dél-Európa országainak többségében kizárólag a házasságkötések száma nőtt. Ebben az időszakban tolódott későbbre az első házasságkötés, illetve a nők esetében az első gyermekszülés életkora is. A többi volt szocialista országhoz hasonlóan Magyarországon is később, csak az 1990-es években kezdett el jelentősen csökkeni a termékenység és a házasodási kedv, ugyanakkor a válási arányszám növekedése ezekben az években megállt, majd újra emelkedett.

\section{A szubjektív jóllét és családi állapot közötti összefüggés}

Kezdetben a szinglikre még az individualizáció előfutáraiként tekintettek (Mächler 1995), akik egyik legfóbb tulajdonságának a függetlenséget tartották (Hertel et al. 2007). Ez, az 1970-es és 1980-as évekre jellemző pozitív kép az 1990-es évektól egyre negatívabbá vált. Ekkortól ugyanis többek között olyan fiatalokkal azonosították őket, akiknek az életében fontos szerepet tölt be a szórakozás (Hradil 2003, Hertel et al. 2007). Hradil (2003, 39. old.) deficittel rendelkezőknek tekintette óket (Defizitfiguren), akiknek hiányzott egy állandó partner a mindennapjaikból.

Ismert továbbá olyan álláspont is, miszerint a szinglik magányosabbak, elégedetlenebbek az életükkel, mint azok, akik tartós párkapcsolatban, házasságban élnek (Cargan 1981, DePaulo-Morris 2005, Diener et al. 1999, Haller-Hadler 2006, Hertel et al. 2007, Hradil 1995, 2003, Ho 2015, Shapiro-Keyes 2008, Verbakel 2012). A házasság ugyanis nemcsak anyagi biztonságot nyújt a felek számára, hanem érzelmi támogatást is jelent (Hradil 2003, Hertel et al. 2007, Verbakel 2012), utóbbi a férfiak esetében jelentősebb, mint a nőknél (Diener et al. 1999).

Cargan (1981) ugyanakkor arra is rámutatott, hogy a szinglikkel kapcsolatos negatív feltételezések nem érvényesek minden ebbe a csoportba tartozóra, és a házasok is gyakran érzik magukat magányosnak. Fontos azonban megjegyezni, hogy a

\footnotetext{
${ }^{4} \mathrm{Az}$ az életszakasz, melyben a fiatal már nem kamasz, még nem felnőtt.
} 
szinglik kevésbé tekintettek az egyedüllétre a boldogtalanság forrásaként, hiszen sokan közülük nem is egyedül élnek.

Egyes kutatások szerint a szubjektív jóllétben családi állapot szerint nincs jelentős különbség (Hertel et al. 2007, DePaulo-Morris 2005). Ugyanis, ha a házasok jellemzőit azokhoz a szinglikéhez viszonyítanánk, akik még sosem kötöttek házasságot, vagyis nőtlen, hajadon családi állapotúak, akkor a két csoport mutatói nem térnének el olyan élesen egymástól (DePaulo-Morris 2005). Ebben az is szerepet játszhat, hogy bár a házasokra jellemzőtől némileg elmaradva, de a szinglik is igen magasra értékelték a szubjektív jóllétüket. A barátokkal, a testvérekkel, a szülőkkel és a gyermekekkel való törődés, jó kapcsolat is pozitív hatással van a szinglik jóllétére (Hertel et al. 2007, Haller-Hadler 2006, Cockrum-White 1985).

Verbakel (2012, 206. old.) a ,jelenlegi párkapcsolati státust” (current partnership status) alkalmasabbnak találta a szubjektív jóllét vizsgálatához, mint a törvényes családi állapotot. Példaként hozva erre egy özvegy esetét, aki bár időközben újra párkapcsolatban élhet, családi állapotát tekintve mégis özvegynek számít. A részletesebb kategóriákat tartalmazó párkapcsolati státus szerinti bontást alkalmazva arra a következtésre jutott, hogy a házasok a legelégedettebbek az életükkel, őket követik az élettársak, a látogató párkapcsolatban (living apart together - LAT) élők, a szinglik, az özvegyek, végül pedig az elváltak.

\section{Adatok és módszerek}

Jelen tanulmány a 2001. és a 2011. évi népszámlálás, valamint a 2016. évi mikrocenzus adatai alapján mutatja be a szinglinépesség főbb társadalmi, területi jellemzőit. Továbbá a szubjektív, egyéni értékelésen alapuló életkörülményeit is vizsgálja a 2016. évi mikrocenzus szubjektív jólléttel foglalkozó, a 16 éves és idősebb népesség körében végzett kiegészítő felvételének eredményei alapján.

Bár a népszámlálási adatok a szingliléttel kapcsolatos okokra nem adnak magyarázatot, lévén az egyetlen teljes népességre kiterjedô adatfelvétel, így mégis alkalmasnak, kulcsfontosságúnak tartjuk a szinglik főbb jellemzőinek bemutatására. A mikrocenzus kiegészítő felvétele segítségével azonban már arra is lehetőségünk nyílt, hogy összefüggéseket, kapcsolatokat keressünk az egyes szempontok között.

\section{Kutatási eredmények}

A 2016. évi mikrocenzus eszmei időpontjában a szinglik túlnyomó többsége (75\%-a) 20-39 éves volt. A 20-39 éves, továbbiakban fiatalabb szinglinek tekintett népesség száma 2001 és 2011 között 139-ről 201 ezer főre nőtt, 2016-ra azonban 188 ezer főre csökkent. Az idősebb, 40-49 éves szinglik száma 2001 és 2016 között folyamatosan emelkedett, és az időszak végére megközelítette a 63 ezer főt. A 20-39 éves nőtlen, hajadon családi állapotú népesség 11, a 40-49 éveseknek pedig a 17\%-a

Területi Statisztika, 2020, 60(2): 224-248; DOI: 10.15196/TS600206 
számított szinglinek, vagyis nem volt se élettársa, se gyermeke, egyedül élt egy háztartásban 2016-ban.

A szinglik számának alakulása nemenként, korcsoportok szerint

Number of singles by sex and age group

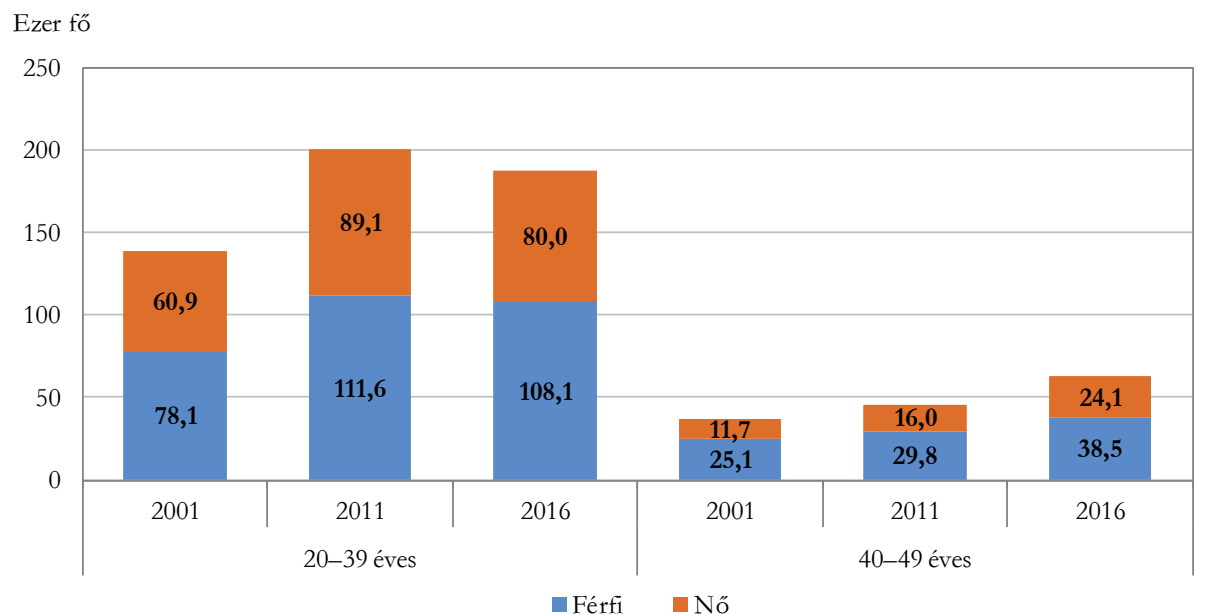

Forrás: saját számítás a 2001. és a 2011 évi népszámlálás, valamint a 2016. évi mikrocenzus adatai alapján.

Mind a fiatalabb, mind az idősebb szinglik között több a férfi, mint a nő. Ennek többek között az is lehet az oka, hogy több fiúgyermek születik, mint leány, és ez a férfitöbblet egészen a 40-es évei végéig jellemzi a népességet.

A szinglik számának alakulásában a házasságkötési szokások változása, a házasságkötés és a gyermekvállalás átlagos életkorának kitolódása, valamint az iskolázottsági szint emelkedése is szerepet játszhatott. A 2000-es évek elejétól 2010-ig csökkent, majd ezt követően újra nőni kezdett a teljes első házasságkötési arányszám. Míg ugyanis 2000-ben száz hajadon közül 49, 2011-ben mindössze 39, addig 2016-ban már 66 kötné meg első házasságát 50 éves koráig, ha az adott év házasságkötési gyakorisága tartósan fennállna. Érdemes azt is megjegyezni, hogy az első házasságkötés átlagos életkora 1990 és 2018 között a nők és a férfiak esetében egyaránt 8 évvel emelkedett. Míg 1990-ben a férfiak átlagosan 25, illetve a nők 22 éves korukban álltak először anyakönyvvezetô elé, addig 2018-ban már 33, illetve 30 évesen. Nemcsak a házasságkötés, de a gyermekvállalás átlagéletkora is kitolódott. A nők 1990-ben átlagosan 23, 2018-ban 29 évesek voltak az első gyermekük megszületésekor (KSH 2019). 
3. ábra

A szinglik legmagasabb iskolai végzettség szerinti megoszlása nemenként, korcsoportok szerint, 2016

Distribution of singles by educational attainment, sex and age group, 2016

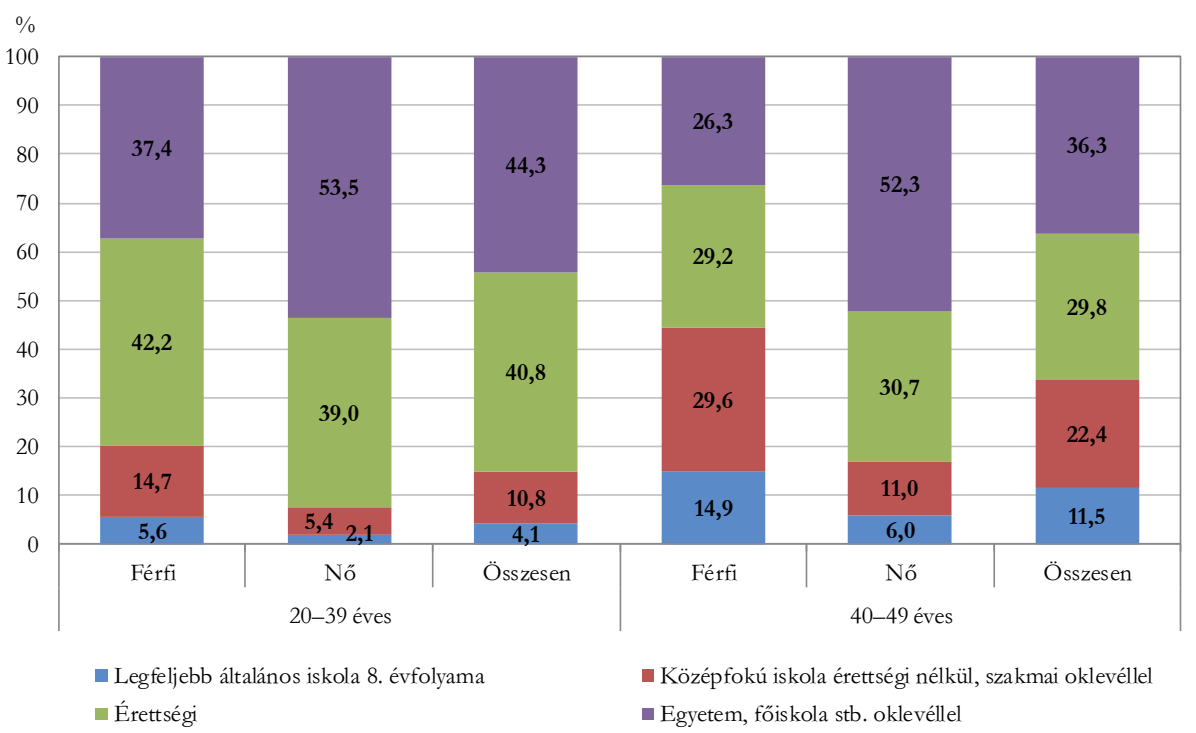

Forrás: saját számítás a 2016. évi mikrocenzus adatai alapján.

Az elmúlt évtizedekben folyamatosan nőtt a felsőfokú iskolai végzettséggel rendelkezők aránya Magyarországon, a területi különbségek pedig csökkentek, melyben az is szerepet játszhatott, hogy Budapest és a nagyvárosok e téren betöltött szerepe valamelyest mérséklődött (Németh-Dövényi 2018). Míg 2001-ben a 20 éves és idősebb népesség 12, 2016-ban már 22\%-ának (1 millió 716 ezer főnek) volt felsőfokú végzettsége (KSH 2017). Ugyanez az arány a fiatalabb szinglik esetében 44, az idősebbek körében 36\% volt a 2016. évi mikrocenzus adatai szerint. A felsőfokú végzettségúek aránya - az országoshoz hasonlóan - a nők körében magasabb volt, mint a férfiak esetében.

Területi Statisztika, 2020, 60(2): 224-248; DOI: 10.15196/TS600206 
Egy átlagos szingli néhány jellemzője nemenként, korcsoportok szerint, 2016

Some characteristics of an average single by sex and age group, 2016

\begin{tabular}{l|c|c|c|c}
\hline \multirow{2}{*}{ Megnevezés } & \multicolumn{2}{|c|}{$20-39$ éves } & \multicolumn{2}{c}{$40-49$ éves } \\
\cline { 2 - 5 } & férfi & nő & férfi & nő \\
\hline Átlagéletkor, év & 30,3 & 29,6 & 43,9 & 43,8 \\
Először önálló házba/lakásba költözés átlagéletkora, év & 24,1 & 23,5 & 28,7 & 27,9 \\
Először kezdtek el rendszeresen dolgozni, átlagéletkor, év & 20,9 & 21,3 & 19,1 & 20,2 \\
Havi nettó átlagjövedelem, ezer forint & 201,2 & 181,3 & 172,7 & 192,6 \\
Havi nettó mediánjövedelem, ezer forint & 170,0 & 150,0 & 115,0 & 200,0 \\
\hline
\end{tabular}

Forrás: saját számítás a 2016. évi mikrocenzus adatai alapján.

A 2016. évi mikrocenzus adatai szerint míg a 20-39 éves szinglik átlagosan a 20-as éveik elején, addig a 40-49 évesek annak vége felé költöztek első alkalommal önálló lakásba vagy házba. A fiatalabb korcsoportba tartozók némileg későbbi életkorban kezdtek el elôször rendszeresen dolgozni, mint az idősebb korcsoportba tartozók. A havi nettó átlagjövedelem szempontjából is jelentősek a különbségek a szinglik két korcsoportja között. Ugyanis a 20-as és a 30-as éveikben járó szingliférfiak magasabb, a velük egykorú szinglinők alacsonyabb nettó jövedelemmel rendelkeztek, mint a 40-49 évesek.

2. tábla

\section{Az öt leggyakrabban előforduló foglalkozás a szinglik körében nemenként, korcsoportok szerint, 2016}

The five most common occupations among singles by sex and age group, 2016

\begin{tabular}{|c|c|c|c|c|}
\hline \multirow{2}{*}{ Foglalkozás } & \multicolumn{2}{|c|}{ 20-39 éves } & \multicolumn{2}{|c|}{ 40-49 éves } \\
\hline & férfi & nő & férfi & nő \\
\hline 1. foglalkozás & $\begin{array}{c}\text { Szoftverfejlesztő } \\
(3,2 \%)\end{array}$ & $\begin{array}{c}\text { Bolti eladó } \\
(4,6 \%)\end{array}$ & $\begin{array}{c}\text { Lakatos } \\
(4,2 \%)\end{array}$ & $\begin{array}{c}\text { Bolti eladó } \\
(5,1 \%)\end{array}$ \\
\hline 2. foglalkozás & $\begin{array}{l}\text { Lakatos } \\
(2,4 \%)\end{array}$ & $\begin{array}{c}\text { Általános irodai } \\
\text { adminisztrátor } \\
(4,0 \%)\end{array}$ & $\begin{array}{c}\text { Tehergépkocsi- } \\
\text { vezető, kamion- } \\
\text { soför }(2,8 \%) \\
\end{array}$ & $\begin{array}{c}\text { Általános irodai } \\
\text { adminisztrátor } \\
(4,5 \%)\end{array}$ \\
\hline 3. foglalkozás & $\begin{array}{c}\text { Rendszergazda } \\
(1,9 \%) \\
\end{array}$ & $\begin{array}{l}\text { Pultos } \\
(2,0 \%) \\
\end{array}$ & $\begin{array}{c}\text { Vagyonőr, testőr } \\
(2,4 \%)\end{array}$ & $\begin{array}{l}\text { Középiskolai } \\
\text { tanár }(3,8 \%)\end{array}$ \\
\hline 4. foglalkozás & $\begin{array}{c}\text { Bolti eladó } \\
(1,9 \%)\end{array}$ & $\begin{array}{c}\text { Pénzügyi ügyin- } \\
\text { téző } \\
(1,9 \%) \\
\end{array}$ & $\begin{array}{c}\text { Bolti eladó } \\
(2,0 \%)\end{array}$ & $\begin{array}{c}\text { Általános } \\
\text { iskolai tanár, } \\
\text { tanító }(2,9 \%)\end{array}$ \\
\hline 5. foglalkozás & $\begin{array}{l}\text { Tehergépkocsi- } \\
\text { vezetô, } \\
\text { kamionsofőr } \\
(1,8 \%)\end{array}$ & $\begin{array}{c}\text { Pénzügyi } \\
\text { elemző, befekte- } \\
\text { tési tanácsadó } \\
(1,8 \%)\end{array}$ & $\begin{array}{c}\text { Kőműves } \\
(1,8 \%)\end{array}$ & $\begin{array}{c}\text { Számviteli } \\
\text { ügyintéző } \\
(1,9 \%)\end{array}$ \\
\hline
\end{tabular}

Forrás: saját számítás a 2016. évi mikrocenzus adatai alapján. 
A szinglik jellemzőit abból a szempontból is megvizsgáltuk, mely foglalkozások fordultak elő körükben a leggyakrabban 2016-ban. Az adatok értelmezése során fontos azt szem előtt tartani, hogy a szinglik heterogén csoportot alkotnak, ami foglalkozásuk sokszínúségében is megmutatkozik. Éppen ezért az első öt helyen álló foglalkozás esetében is viszonylag alacsonyak az arányok. Míg az idősebb szingliférfiak esetében a lakatos, addig a fiatalabbaknál a szoftverfejlesztő található az első helyen. Mind a 20-39, mind a 40-49 éves szinglinôk közül bolti eladóként és általános irodai adminisztrátorként dolgoztak a legtöbben. A foglalkozások sorrendje a továbbiakban azonban a két korcsoport esetében eltért egymástól.

A szinglik népességen belüli aránya járásonként különbözik, a 4. ábra a 20-39 és a 40-49 éves szinglik arányát mutatja járási szinten, a 2016. évi mikrocenzus adatai alapján. A területi különbségek elemzése előtt fontos azonban azt is megjegyezni, hogy 2011 és 2016 között tíz járás közül nyolcban csökkent a szinglik aránya a 20-39 éves nőtlen, hajadon családi állapotú népességen belül. A legnagyobb mértékủ, 4,8 százalékpontos visszaesés a Komlói járásban következett be, ahol 2016-ban a nőtlen, hajadon családi állapotú népesség 4,1\%-a számított szinglinek. Legnagyobb mértékben, 7,6-ról 11,0\%-ra a Balatonfüredi járásban nőtt a fiatalabb szinglik aránya. Akárcsak 2011-ben, úgy 2016-ban is Budapesten élt arányaiban a legtöbb 20-39 éves szingli, ahol minden negyedik, ebbe a korcsoportba tartozó, nőtlen, hajadon családi állapotú szingli volt. A fóváros után azokban a járásokban volt a legnagyobb a szinglik hányada, amelyek megyeszékhelyet is magukban foglaltak, például a Debreceni (21\%), a Szegedi (18\%) és a Pécsi (17\%) járásokban.

A 40-49 éves nőtlen, hajadon családi állapotú népesség esetében is a szinglik aránya szinte valamennyi járásban csökkent 2011 és 2016 között. Bár 2011-hez képest Budapesten is kevesebben tartoztak ebbe a csoportba, azonban - fiatalabb társaikhoz hasonlóan - továbbra is itt (29\%) számított a legtöbb 40-49 éves nőtlen, hajadon családi állapotú szinglinek. A fôváros és a Szegedi járás után (25\%) fôként az országhatárhoz közeli, többnyire községeket tartalmazó járásokban volt a legmagasabb az idősebb szinglik népességen belüli aránya.

Területi Statisztika, 2020, 60(2): 224-248; DOI: 10.15196/TS600206 
A 20-39 és a 40-49 éves szinglik aránya

a nőtlen, hajadon népességen belül, járásonként, 2016

Proportion of singles aged 20-39 and 40-49

within the never-married population, by district, 2016

20-39 éves szinglik

20-39 year-old singles

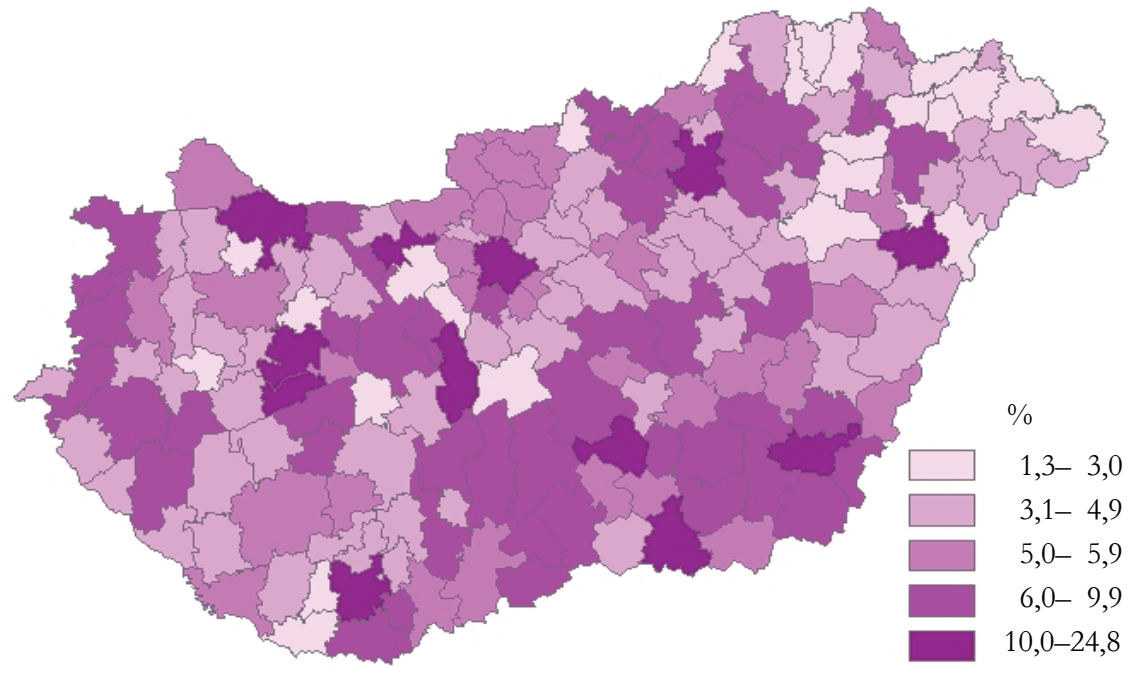

40-49 éves szinglik

40-49 year-old singles

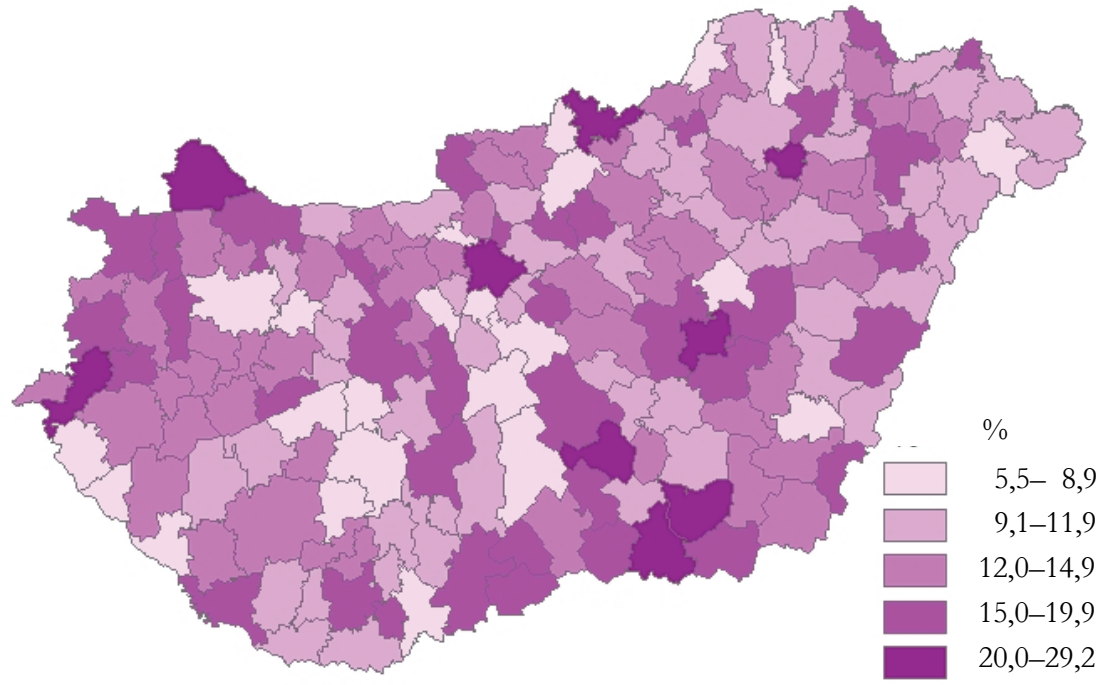

Forrás: saját szerkesztés a 2016. évi mikrocenzus adatai alapján.

Területi Statisztika, 2020, 60(2): 224-248; DOI: 10.15196/TS600206 
Az életkörülményeket nemcsak az eddig részletezett objektív tényezőkkel, hanem szubjektív mutatók segítségével is vizsgálhatjuk. Míg az előbbiek segítségével objektív tényadatokat kaphatunk, addig utóbbiak az egyén által megélt, szubjektív élethelyzeten alapulnak. A szubjektív jóllét - az OECD definíciója szerint - „az embereknek a velük történt eseményekkel, a testükkel, a gondolataikkal és az életkörülményeikkel, összességében az életükkel kapcsolatos különböző értékelések gyúitőfogalma” (KSH 2014, 6. old.). Kulcsmutatója az élettel való elégedettség, de a jellemző érzelmi állapotok is fontos részei a szubjektív jóllét vizsgálatának. A tanulmány további részében a szinglik életkörülményeit az élettel való elégedettségen, valamint egy pozitív (boldogság) és egy negatív (magányosság) érzelem megélésének gyakoriságán keresztül mutatjuk be, összehasonlítva a házasságban élők megfelelő jellemzőivel.

5. ábra

$\mathrm{Az}$ élettel és annak bizonyos területeivel való elégedettség átlagértékei a szinglik és a házas családi állapotúak körében, 2016

Average satisfaction with life and its certain areas among singles and married people, 2016

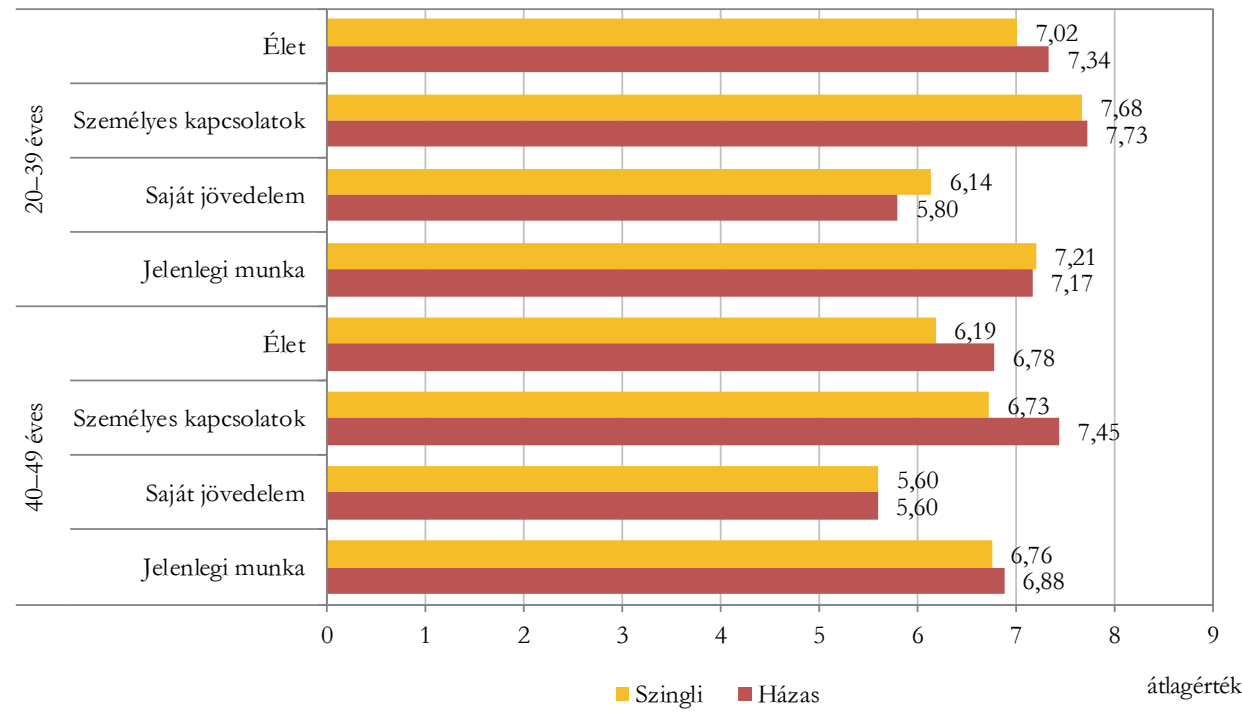

Forrás: saját számítás a 2016. évi mikrocenzus adatai alapján.

Mind a 20-39, mind a 40-49 éves szinglik 2016-ban elégedetlenebbek voltak az életükkel ${ }^{5}$, mint az ugyanezen korcsoportokba tartozó házas családi állapotúak. Figyelemre méltó továbbá, hogy a 40-49 éves szinglik szinte az élet valamennyi

${ }^{5}$ Az élettel és annak meghatározott területeivel való elégedettséget egy 0-tól 10-ig terjedő skálán vizsgáltuk, ahol a 0 azt jelentette, hogy egyáltalán nem, a 10 pedig azt, hogy teljes mértékben elégedettek voltak.

Területi Statisztika, 2020, 60(2): 224-248; DOI: 10.15196/TS600206 
vizsgált területével kevésbé voltak elégedettek, mint a velük egykorú házasok. A 20-39 éves szinglik ezzel szemben a jövedelmi helyzetükkel elégedettebbek voltak a házasoknál, ami többek között talán azzal is összefügg, hogy a szinglik között arányaiban többen rendelkeztek felsőfokú iskolai végzettséggel, ami magasabb fizetéssel járó munkahelyet jelenthet a számukra. Bár az élettel való átlagos elégedettség a szinglik mindkét korcsoportjában elmaradt a házas családi állapotúakétól, a fiatalabbak elégedettebbek, az idősebbek elégedetlenebbek voltak, mint a 16 éves és idősebb népesség $(6,41)$.

Nemcsak a szinglik és a házasok, hanem a szinglik két korcsoportja között is jelentősek a különbségek. Ugyanis a 20-39 évesek az életükkel és annak meghatározott területeivel kapcsolatban is magasabb átlagpontszámot adtak, mint az idősebb korcsoportba tartozó társaik. Az élettel való elégedettség az életkor növekedésével fokozatosan csökken (KSH 2018b), melyet a fiatalabb és az idősebb szinglik adatainak értelmezése során is érdemes figyelembe venni.

Az élettel való elégedettség a megyénkénti átlagértékeiben a 40-49 éves szinglik körében nagyobbak a különbségek, mint a 20-39 évesek esetében. A 40-49 éves szinglik közül Fejér megyében $(7,50)$ adták a legmagasabb, Nógrád megyében $(4,63)$ pedig a legalacsonyabb átlagpontszámot. A 20-39 éves szinglik között ennél némileg kisebb az eltérés, akik Komárom-Esztergom megyében $(7,87)$ voltak legelégedettebbek az életükkel, legkevésbé pedig Zala megyében $(5,86)$.

Fontos megjegyezni, hogy a fiatalabb és az idősebb szinglik, valamint a velük egykorú házasok is gyakrabban éltek meg pozitív, mint negatív érzelmeket a 2016. évi mikrocenzus adatai szerint. Azonban míg a házas családi állapotúakhoz képest arányaiban kevesebben érezték a szinglik közül mindig vagy többnyire boldognak magukat, addig nagyobb részük válaszolta azt, hogy mindig vagy többnyire magányos volt. Amennyiben a szinglikre jellemző arányokat a 16 éves és idősebb népességéhez viszonyítjuk, akkor többek között megállapíthatjuk, hogy a 20-39 éves szinglik boldogabbnak, de egyúttal magányosabbnak is számítottak az országos átlagnál. A 40-49 éves szinglik boldognak ritkábban, magányosnak gyakrabban érezték magukat, mint a 16 évesek és annál idősebbek. 
Az élettel való elégedettség átlagértékei

a 20-39 és a 40-49 éves szinglik körében, megyénként, 2016

Average satisfaction with life among singles aged 20-39 and 40-49, by county, 2016

20-39 éves szinglik

20-39 year-old singles

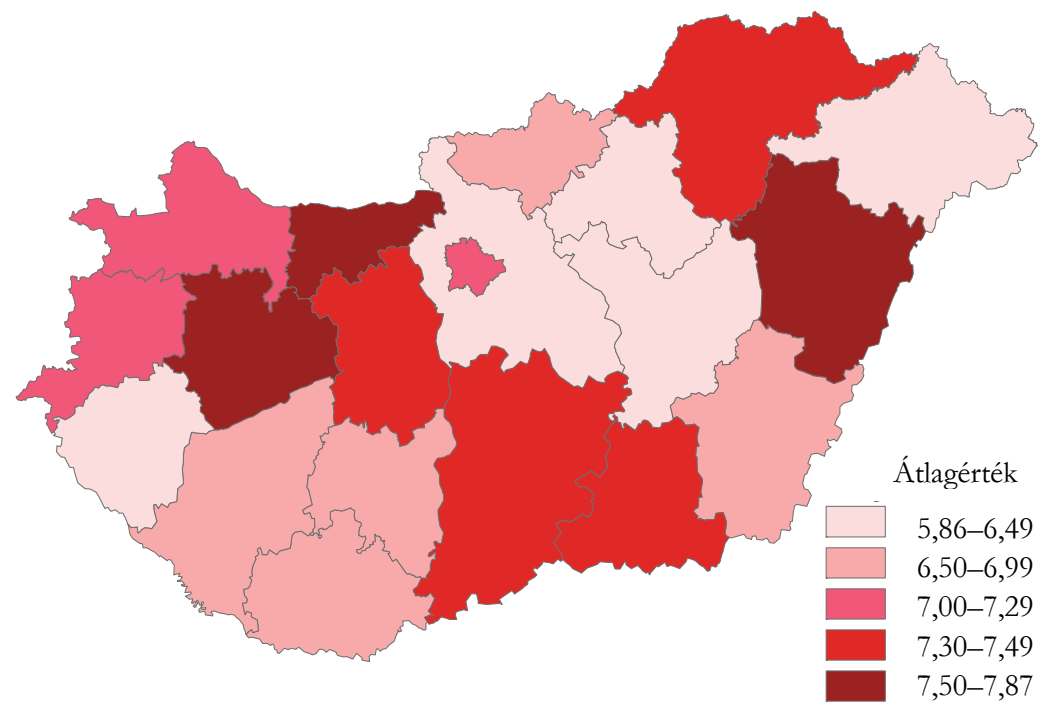

40-49 éves szinglik

40-49 year-old singles

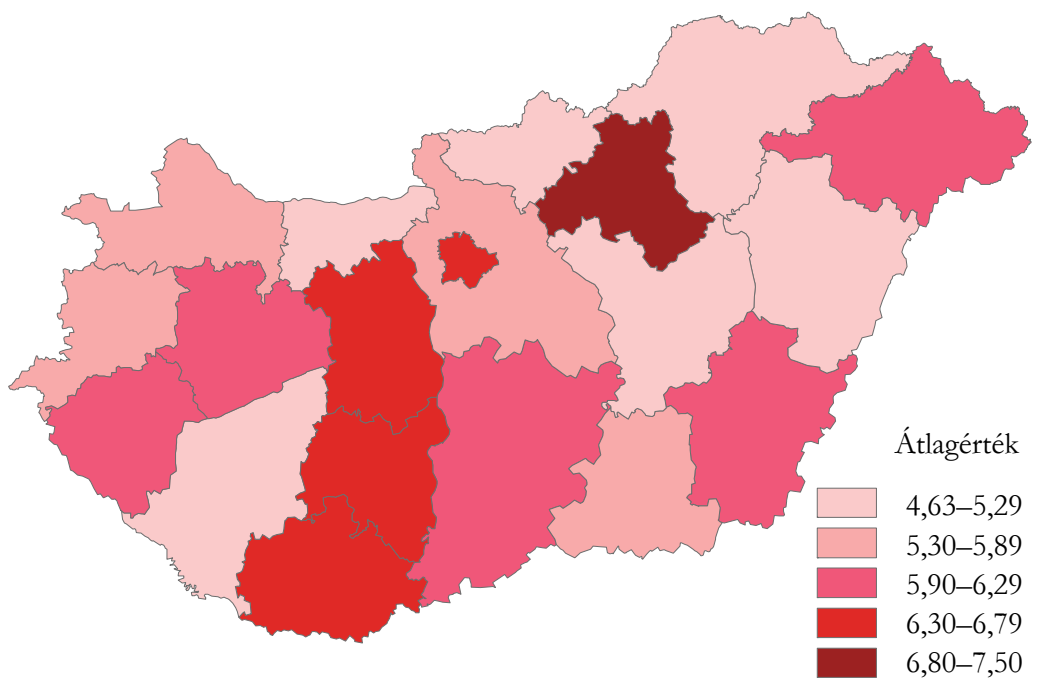

Forrás: saját szerkesztés a 2016. évi mikrocenzus adatai alapján.

Területi Statisztika, 2020, 60(2): 224-248; DOI: 10.15196/TS600206 
A különböző érzelmi állapotok megélésének gyakorisága a szinglik és a házasok körében, 2016

Frequency of experiencing different emotional states among singles and married people, 2016

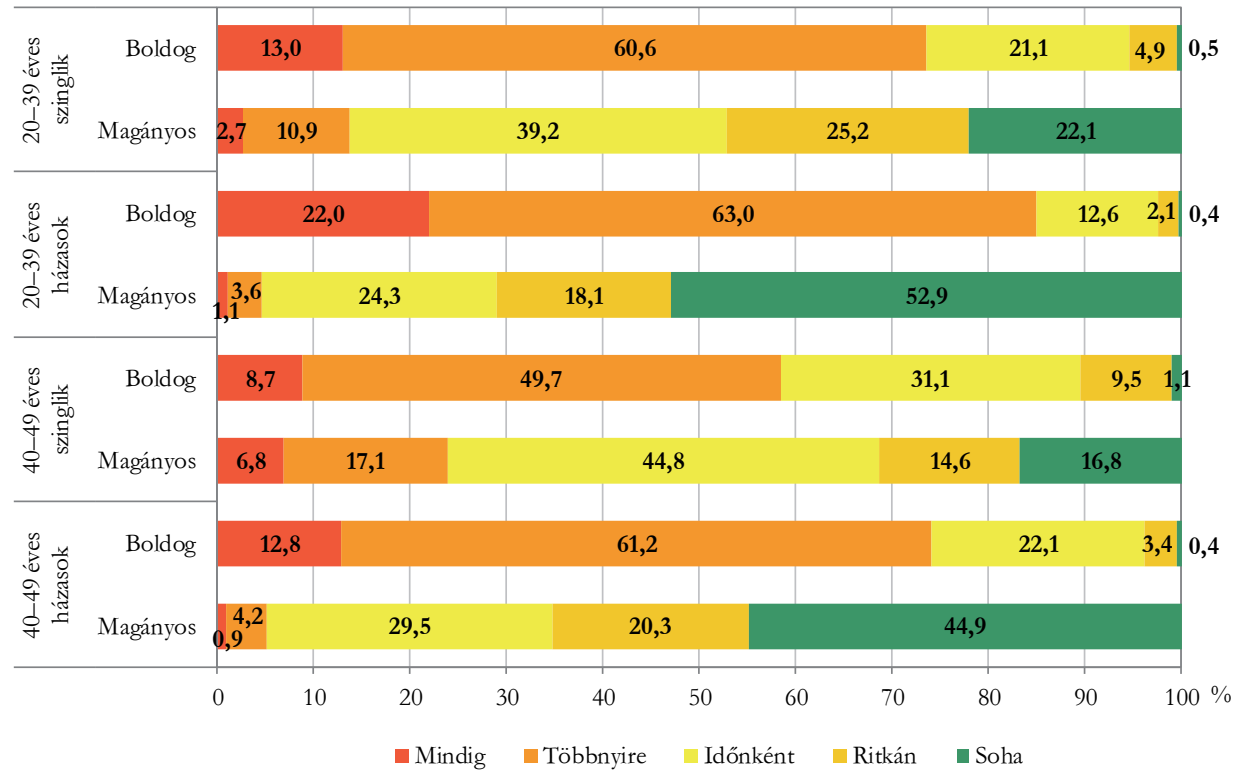

Forrás: saját számítás a 2016. évi mikrocenzus adatai alapján.

A szinglik két korcsoportja között is jelentősek a különbségek a jellemző érzelmi állapotok tekintetében. A 7. ábra megmutatja, hogy a 20-39 éves szinglik gyakrabban érezték magukat boldognak, illetve arányaiban kevesebben válaszolták azt, hogy mindig vagy többnyire magányosak voltak, mint az idősebb korcsoportba tartozó társaik. Az adatok értelmezése során azonban érdemes azt is szem elôtt tartani, hogy a boldogság megélésének gyakorisága szorosan összefügg az életkorral. Ugyanis az életkor előrehaladtával a mindig vagy többnyire boldogok aránya folyamatosan csökken (KSH 2018b), ami talán valamelyest a fiatalabb és az idősebb szinglik közötti eltérést is magyarázhatja. 
A magukat mindig vagy többnyire boldognak érzők aránya a 20-39 és a 40-49 éves szinglik körében, 2016

Proportion of people who always or mostly feel happy among singles aged 20-39 and 40-49, 2016

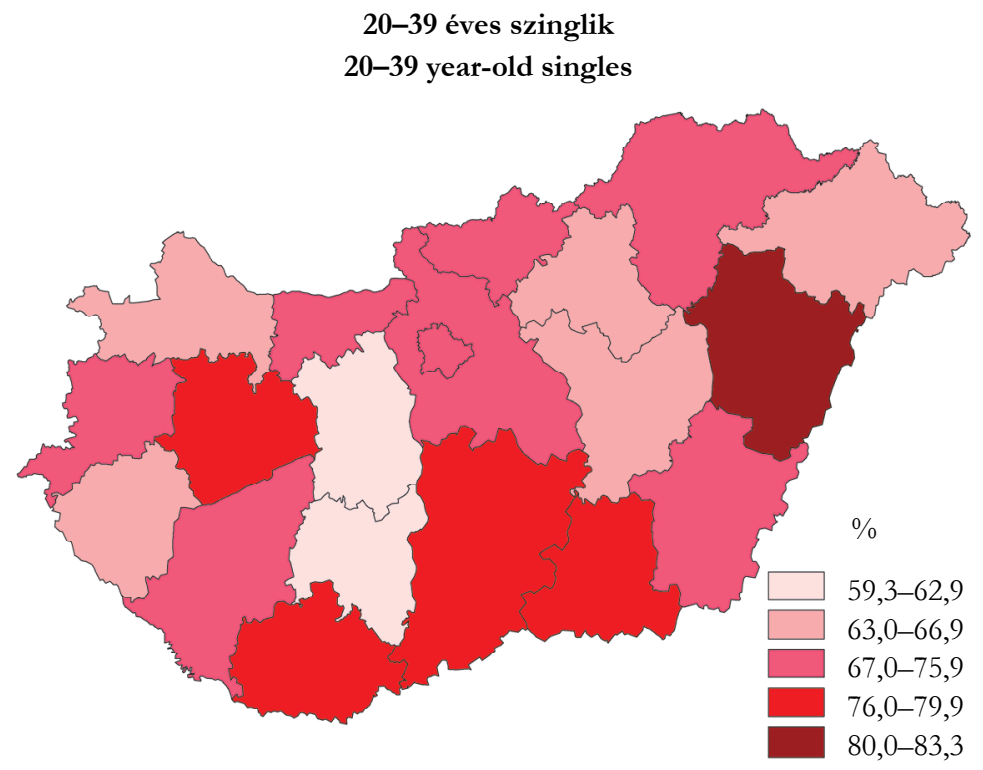

40-49 éves szinglik

40-49 year-old singles

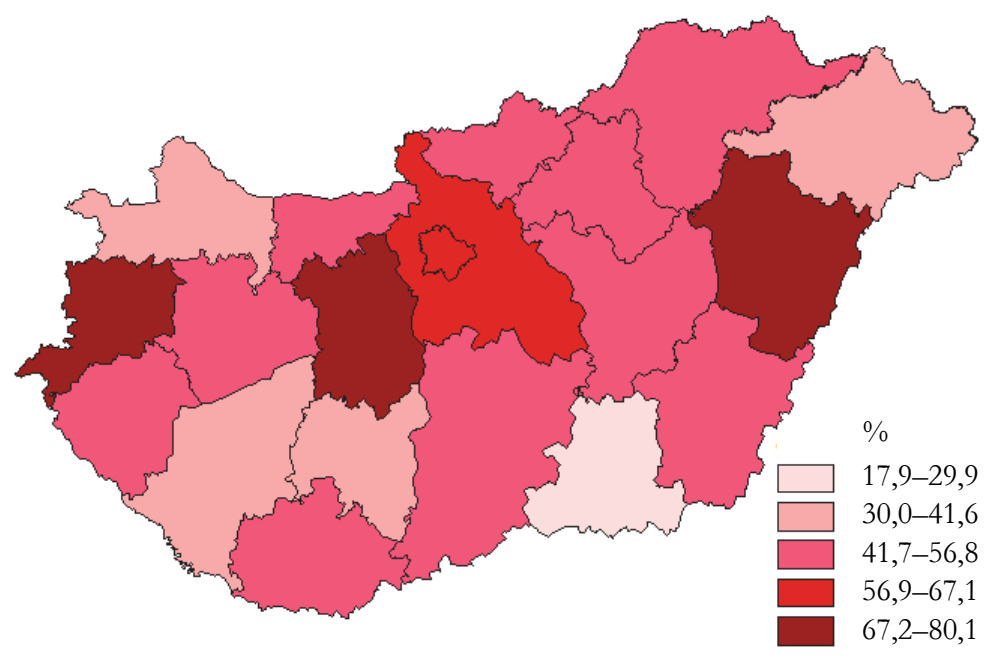

Forrás: saját szerkesztés a 2016. évi mikrocenzus adatai alapján.

Területi Statisztika, 2020, 60(2): 224-248; DOI: 10.15196/TS600206 
A boldogságot az a település is meghatározza, ahol élünk, hiszen azok az emberi, közösségi kapcsolatok is hozzájárulhatnak boldogságunk, életminőségünk alakulásához, melyek ezekhez a helyekhez köthetők (Barsi 2019). Éppen ezért a szinglik érzelmi állapotának vizsgálata során a területi különbségeket is tekintetbe kell venni. A mindig vagy többnyire boldogok arányát mutatja a 8. ábra a fiatalabb és az idősebb szinglik körében. A 2016. évi mikrocenzus adatai szerint a 20-39 éves szingliknek több mint a fele megyétől függetlenül mindig vagy többnyire boldognak érezte magát. Ebben a korcsoportban a boldogságot leggyakrabban megélők aránya HajdúBihar megyében $(83 \%)$ volt a legmagasabb, amitől legalacsonyabb arányával Fejér megye 24 százalékponttal maradt el. A 40-49 évesek esetében a fiatalabbakhoz képest a két szélsőértékkel jellemezhető megye között már jelentősebb az eltérés a boldogság mértékében. Míg ugyanis a Vas megyei idôsebb szinglik 80, addig a Csongrád megyeiek 18\%-a tartotta magát mindig vagy többnyire boldognak.

\section{Összegzés}

Tanulmányunkban összefoglaltuk a szinglikkel kapcsolatos, kutatásunk szempontjából relevánsnak tartott fogalmi meghatározásokat, melyeket alapul véve határoztuk meg azt, hogy kiket is tekintünk szinglinek. Fontos megjegyezni, hogy a szingliken belül két korcsoportot különböztettünk meg, a 20-39 és a 40-49 éveseket, előbbieket fiatalabb, utóbbiakat idősebb szingliknek neveztük. Azokat a nőtlen, hajadon családi állapotú, egyedül élőket soroltuk a szinglik közé, akiknek nem volt se élettársa, se gyermeke. A fogalmi meghatározások után kutatásunk szakirodalmi hátterét, végül pedig a fóbb eredményeket ismertettük.

Kutatási kérdéseink megválaszolásához a 2001. és a 2011. évi népszámlálás, valamint a 2016. évi mikrocenzus adatait használtuk fel. Hiszen a népszámlálás az egyetlen olyan adatfelvétel, amely a teljes népességre kiterjed, így többek között a népesség számában, összetételében történő változások, valamint korlátozások mentén a szinglik jellemzőinek vizsgálatához is fontos adatforrást jelent.

Kutatási eredményeink szerint a 20-39 éves szinglik száma 2001 és 2011 között 139-rôl 201 ezerre nőtt, 2016-ra azonban 188 ezer főre csökkent. Ezzel szemben a 40-49 évesek létszáma ugyanebben az időszakban folyamatosan emelkedett, 2016-ra megközelítette a 63 ezer főt. A teljes népességhez hasonlóan a szinglik körében is nőtt a felsőfokú végzettségűek aránya, azonban a 20-39 évesek nagyobb arányban rendelkeztek felsőfokú végzettséggel, mint az idősebb korcsoport tagjai.

A tanulmány a területi különbségeket is vizsgálta. A 2016. évi mikrocenzus adatai szerint arányaiban a legtöbb 20-39 éves szingli a 2011. évi népszámláláshoz hasonlóan Budapesten, illetve azokban a járásokban élt, amelyek megyeszékhelyet is magukban foglaltak. A 40-49 éves szinglik aránya a fiatalabbakhoz hasonlóan a fôvárosban volt a legmagasabb, melyet a Szegedi járás, valamint az országhatárhoz közeli, fôként községeket tartalmazó járások követtek.

Területi Statisztika, 2020, 60(2): 224-248; DOI: 10.15196/TS600206 
A tanulmány legfontosabb részének talán az tekinthető, amely a szinglik életkörülményeit mutatja be szubjektív mutatók segítségével. Eredményeink többnyire alátámasztják azokat a megállapításokat, melyekre a témával foglalkozó, korábbi kutatások jutottak. Ugyanis a szinglik mindkét csoportja elégedetlenebb volt az életével, illetve ritkábban érezte magát mindig vagy többnyire boldognak, gyakrabban magányosnak, mint a velük egykorú, házas családi állapotúak. Mégis, ha a 16 éves és idôsebb népességhez viszonyítunk, akkor a szinglik közül a 20-39 évesek az átlagosnál elégedettebbnek, boldogabbnak számítottak, amit a személyes kapcsolataikkal való elégedettségük is befolyásolhatott. A 40-49 évesek ezzel szemben elégedetlenebbek voltak, illetve ritkábban érezték magukat boldognak, mint az országos átlag.

\section{Köszönetnyilvánítás}

A tanulmány elkészültét támogató „EFOP-3.6.3-VEKOP-16-2017-00007 azonosítószámú, „Tehetségből fiatal kutató. A kutatói életpályát támogató tevékenységek a felsőoktatásban” megnevezésű projekt a Széchenyi 2020 program keretében, európai uniós (Európai Szociális Alap) társfinanszírozással valósul meg.

A szerző köszönetét fejezi ki kollégáinak, Vörös Csabánénak és Kovács Marcellnak szakmai támogatásukért, Kovács Andreának a tanulmányban szereplő térképek elkészítéséért, valamint Takács Bélánénak szakmai jellegü, támogató javaslataiért.

\section{IRODALOM}

BARSI, B. (2019): A boldogság mint az okos városok mérésének új, lehetséges módszere Területi Statištika 59 (5): 555-574. https://doi.org/10.15196\%2FTS590505

CARgan, L. (1981): Singles: An Examination of Two Stereotypes Family Relations 30 (3): 377-385. https://doi.org/10.2307/584032

Cockrum, J.-White, P. (1985): Influences on the Life Satisfaction of Never-Married Men and Women Family Relations 34 (4): 551-556. https://doi.org/10.2307/584017

DePaulo, B. M.-Morris, W. L. (2005): Singles in Society and in Science Psychological Inquiry 16 (2-3): 57-83. https://doi.org/10.1207/s15327965pli162

Diener, E.-SuH, E. M.-LukAs, R. E.-Smith, H. L. (1999): Subjective Well-Being: Three Decades of Progress Psyhological Bulletin 125 (2): 276-302. https://doi.org/10.1037/0033-2909.125.2.276

FÖLDHÁzI, E. (2008): Az elsö bárasságkötés után. A párkapcsolatok dinamikája, egyszüloós családok. kialakulása és megszúnése Magyarországon a 20. század második. felében Ph.D. értekezés, Budapesti Corvinus Egyetem, Szociológia és Társadalompolitikai Intézet, Budapest.

Haller, M.-Hadler, M. (2006): How Social Relations and Structures Can Produce Happiness and Unhappiness: An International Comparative Analysis Social Indicators Research 75 (2): 169-216. https://doi.org/10.1007/s11205-004-6297-y

Területi Statisztika, 2020, 60(2): 224-248; DOI: 10.15196/TS600206 
HARCSA, I.-MONOSTORI, J. (2014): Demográfiai folyamatok és a családformák pluralizációja Magyarországon In: KOLOSI, T.-TóTH, I. GY. (szerk.): Társadalmi Riport 2014 pp. 83-109., TÁRKI, Budapest.

Hertel, J.-Schütz, A.-DePaulo, B. M.-Morris, W. L.-Stucke, T. S. (2007): She's single, so what? Zeitschrift für Familienforschung 19 (2): 139-158.

Ho, J-H. (2015): The problem group? Psychological wellbeing of unmarried people living alone in theRepublic of Korea Demographic Research 32 (47): 1299-1328. https://doi.org/10.4054/DemRes.2015.32.47

Hradil, S. (1995): Die „Single-Gesellschaft”Verlag C. H. Beck, München.

HradiL, S. (2003): Vom Leitbild zum "Leidbild": Singles, ihre veränderte Wahrnehmung und der "Wandel des Wertewandels" Zeitschrift für Familienforschung 15 (1): 38-54.

KeITH, P. (2008): Resources, Family Ties, and Well-Being of Never-Married Men and Women Journal of Gerontological Social Work 42 (2): 51-75. https://doi.org/10.1300/J083v42n02_05

KSH (2014): A jóllét magyarországi indikétorrendszere, 2013 Budapest

KSH (2017): Mikrocenzus 2016. 4. Iskolázottsági adatok Budapest.

KSH (2018a): Mikrocenzus 2016. 6. A háztartások és a családok adatai Budapest.

KSH (2018b): Mikrocenzus 2016. 11. Szubjektiv jóllét Budapest

KSH (2019): Demográfiai évkönyv, 2018 Budapest.

LASLETT, P. (1972): Household and Family in Past Time Harvard University Press, Cambridge.

Monostori, J. (2013): Az egyszülôs családdá válás társadalmi meghatározottsága socio.hu 2013/3: 22-44.

LESTHAEGHE, R.-SURKYN, J. (2012): When History moves on: Foundations and Diffusion of a Second Demographic Transition In: Jayakody, R.-ThorTon, A.-Axinn, W. (szerk.): International Family Change: Ideational Perspectives pp. 81-118., Routledge, New York.

Monostori, J. (2015): Az egyszülős családdá válás az életútban és annak demográfiai meghatározói Demográfia 58 (1): 27-56.

Monostori, J.- Murinkó L. (2018): 9. Háztartás- és családszerkezet In: MONOSTORI, J.ŐRI, P.-SPÉDER, Zs. (szerk.): Demográfiai portré 2018. Jelentés a magyar népesség helyzetéröl pp. 177-197. KSH Népességtudományi Kutatóintézet, Budapest.

Murinkó, L.-SPÉDER, Zs. (2015): Párkapcsolatok In: MONOSTORI, J.-Ő́RI, P.-SPÉder, Zs. (szerk.): Demográfiai portré 2015. Jelentés a magyar népesség helyzetéról pp. 9-26., KSH Népességtudományi Kutatóintézet, Budapest.

MurinkÓ, L. (2013): Elsố elköltözés a sqüloói háaból Magyarországon. A szülōi ház elhagyásának időzitése, párkapcsolati környezete és családi háttér szerinti különbségei Központi Statisztikai Hivatal Népességtudományi Kutatóintézetének Kutatási jelentései 94. Budapest.

MÄCHLER, R. (1995): Alleinleben - eine individualisierte Lebensform? Zeitschrift für Familienforschung 7 (2): 149-178. 
NÉMETH, Á.-DÖVÉNYI, Z. (2018): „Kiművelt emberfők a térben” - A diplomások területi eloszlása valóbban a kiegyenlítődés irányában hat? Területi Statisætika 58 (2): 129-150. https://doi.org/10.15196/TS580201

RÖVID, I. (2018): Pillanatfelvétel a szinglikről - A szinglik általános és területi jellemzői a népszámlálási adatok alapján Területi Statisz̨tika 58 (3): 302-318.

https://doi.org/10.15196/TS580304

SCHAD-SEIFERT, A. (2019): Japans Single-Gesellschaft - Der Trend zu Partnerlosigkeit in Umfragen des National Institute of Population and Social Security Research In: SCHAD-SEIfERT, A.-KotTMAnN, N. (eds) Japan in der Krise pp. 75-97., Springer VS, Wiesbaden.

SCHADT, M.-PÓTÓ, Zs. (2014): A strukturális változások hatása a nők társadalmi szerepeire és a családszerkezet átalakulására In: SPÉDER, Zs. (szerk.): Demográfus Könyvtár 2. pp. 217-243. KSH Népességtudományi Kutatóintézet, Budapest.

Shapiro, A.-KEYES, C. L. M. (2008): Marital Status and Social Well-Being: Are the Married Always Better Off? Social Indicators Research 88 (2): 329-346. https://doi.org/10.1007/s11205-007-9194-3

SobotkA, T. (2008): The diverse faces of the Second Demographic Transition in Europe Demographic Research 19 (8): 171-224. https://doi.org/10.4054/DemRes.2008.19.8

SoBotKa, T.-Toulemon, L. (2008): Changing family and partnership behaviour: Common ternds and persistent diversity across Europe Demographic Research 19 (6): 85-138. https://doi.org/10.4054/DemRes.2008.19.6

SOMLAI, P. (1999): A sokféleség zavara: A családi életformák pluralizációja Magyarországon Demográfia 42 (1-2): 38-47.

SOMLAI, P. (2002): Húsz év: családi kapcsolatok változásai a 20. század végi Magyarországon Új Mandátum, Budapest.

SPÉDER, Zs. (2004): Gyermekvállalás és a párkapcsolatok átalakulása In: KOLOSI, T.-TÓTH, I. Gy.-VukOvich, GY. (szerk.): Társadalmi riport 2004. pp. 137-151., TÁRKI, Budapest.

SPÉDER, Zs. (2005a): Az európai családformák változatossága: párkapcsolatok, szülöi és gyermeki szerepek az európai országokban az ezredfordulón Századvég 10 (37): 3-47.

SPÉDER, Zs. (2005b): Az élettársi kapcsolat térhódítása Magyarországon és néhány szempont a demográfiai átalakulás értelmezéséhez Demográfia 48 (3-4): 187-217.

SpÉDER, Zs. (2007): The Diversity of Family Structure in Europe Demográfia 50 (5) English Edition: 105-134.

SPÉDER Zs. - KAPITÁNY B. (2007): Gyermekek: Vágyakés tények. Dinamikus termékenységi elemzések Központi Statisztikai Hivatal - Népességtudományi Kutatóintézet, Budapest.

Spéder, Zs.-KAMARÁs, F. (2008): Hungary: Secular Fertility Decline with Distinct Period Flucktuations Demographic Research 19 (18): 599-664.

TÁRKÁNYI, Á. (2008): A második demográfiai átmenet néhány főbb tényezője a fejlett világban és Magyarországon Demográfia 51 (4): 406-440.

Területi Statisztika, 2020, 60(2): 224-248; DOI: 10.15196/TS600206 
TÓTH, O. (2006): Családformák és együttélési minták a mai magyar társadalomban TÁRKI, Munkaügyi Minisztérium Egyenlő Esélyek Titkársága, Budapest.

UTASI, Á. (2003): Independent, never married people in their thirties: remaining single Demográfia 48 (5): 122-143.

UTASI, Á. (2004): Feláldozott kapcsolatok A magyar szingli MTA Politikai Tudományok Intézete, Budapest.

UTASI, Á. (2005): Feláldozott kapcsolatok A magyar szingli MTA Politikai Tudományok Intézete, Budapest.

VAN DE KAA, D. J. (2002): The idea of the Second Demographic Transition in Industralized Countries Paper presented at the Sixth Welfare Policy Seminar of the National Institute of Population and Social Security, Tokyo, Japan, 29 January 2002.

VAskovics, L.-Rost, H.-Engel, S.-Mattstedt, S.-SmolkA, A. (2000): Älterwerden als Single. Staatsinstitut für Familienforschung an der Universität Bamberg (ifb), Bamberg.

VASKOVICS, L. (2014): Családszerkezeti átalakulások európai kitekintésben Szociológiai Szemle 24 (1): 5-39.

Verbakel, E. (2012): Subjective Well-Being by Partnership Status and Its Dependence on the Normative Climate European Journal of Population 28 (2): 205-232. https://doi.org/10.1007/s10680-012-9257-2. 